\title{
OPTIMALISASI PEMANFAATAN HUTAN KOTA DI DESA SIDEROJO KECAMATAN PAKAL SURABAYA
}

\author{
Suwarno Abadi ${ }^{1}$, Farina Gandryani ${ }^{2}$ \\ ${ }^{1}$ Universitas Wijaya Putra Surabaya \\ ${ }^{2}$ Universitas Wijaya Putra Surabaya \\ suwarnoabadi@uwp.ac.id, farina.gdr@gmail.com
}

\begin{abstract}
Abstrak
Hutan Kota yang terletak di Desa Sidorejo Kecamatan Pakal adalah salah satu dari beberapa hutan kota yang ada di kota Surabaya. Hutan kota di desa Sidorejo ini dapat menjadi alternative tempat berlibur dan sekaligus dapat menjadi tempat untuk menambah income bagi masyarakat sekitar. Adanya beberapa keterbatasan di Hutan kota ini yang mengakibatkan hutan ini jarang dikunjungi oleh warga sekitar terlebih oleh warga dari luar Kecamatan pakal. Disinilah pentingnya pendampingan terhadap masyarakat yang berada di desa Sidorejo dalam rangka untuk mengoptimalisasi pemanfaatan hutan kota pakal. Pendampingan ini dilaksanakan dengan tujuan agar masyarakat memahami bahwa keberadaan hutan kota selain untuk tempat berlibur yang murah meriah dapat juga dimanfaatkan untuk meningkatkan kesejahteraan masyarakat sekitar yang ada di desa Sidorejo. Kegiatan pendampingan dilakukan dengan mengidentifikasi beberapa keterbatasan dan peluang-peluang yang dapat dilaksanakan untuk mengatasi keterbatasan tersebut. Hasil dari kegiatan pendampingan ini adalah adanya akses masuk ke hutan kota yang lebih memadai, adanya lahan parkir bagi pengunjung dan penataan ulang lapak lapak pedagang makanan dan minuman di area hutan kota.
\end{abstract}

Kata Kunci : Optimalisasi, Hutan Kota, Pendampingan

\section{PENDAHULUAN}

Hutan Kota Pakal adalah satu dari lima hutan kota yang terdapat di wilayah kota Surabaya. Letak hutan kota pakal sendiri terletak di RW 01 desa Sidorejo kelurahan Pakal Kecamatan Benowo dengan luas 6.5 Ha. Definisi hutan kota sendiri menurut Peraturan Pemerintah Nomor 63 Tahun 2002 tentang Hutan Kota adalah suatu hamparan lahan yang bertumbuhan pohon-pohon yang kompak dan rapat di dalam wilayah perkotaan baik pada tanah negara maupun tanah hak, yang ditetapkan sebagai hutan kota oleh pejabat yang berwenang. Secara umum Pembangunan hutan kota merupakan amanah dari Undang undang No. 26 Tahun 2007. Amanah ini secara tegas tertuang di Pasal 29 Ayat
(3) yang menyebutkan bahwa proporsi ruang terbuka hijau publik pada wilayah perkotaan adalah minimal 20 persen dari luas wilayah kota. Secara umum pengertian dari ruang terbuka hijau adalah suatu lahan atau kawasan yang ditetapkan sebagai ruang terbuka untuk tempat tumbuhnya tanaman/vegetasi yang berfungsi sebagai pengatur iklim mikro, daerah resapan air, dan estetika kota. Ruang terbuka hijau kota meliputi ruang terbuka hijau publik dan ruang terbuka hijau privat, dengan total luas sebesar 30\% dari luas wilayah daratan kota. Ruang terbuka hijau pada dasarnya dikelompokkan menjadi tujuh kelompoak, yaitu : RTH makam, RTH lapangan dan stadion, RTH telaga/waduk/boezem, RTH dari fasum dan fasos pemukimanRTH kawasan lindung, RTH hutan kota dan RTH taman dan jalur hijau.

$$
\text { Ekonomi, Sosial, dan Budaya }
$$


Hutan kota Pakal yang masuk dalam kelompok RTH hutan kota apabila dilihat dari tujuannya, pembangunan hutan kota bertujuan untuk mewujudkan kelestarian, keserasian dan keseimbangan ekosistem perkotaan yang baik. Hal ini dilakukan dengan tujuan untuk memperbaiki dan menjaga iklim mikro, nilai estetika dan fungsi resapan air serta menciptakan keseimbangan dan keserasian lingkungan fisik kota dan mendukung pelestarian keanekaragaman hayati (Andayaningsih,2013). Selain itu hutan kota juga memiliki fungsi yang lain, yaitu : fungsi penyehatan lingkungan, fungsi pengawetan, fungsi estetika, fungsi perlindungan, fungsi produksi dan fungsi lainnya (Dahlan, 2004).

Melihat potensi besar yang dapat dimanfaatkan dari keberadaan hutan kota ini, maka salah satu kegiatan Kuliah Kerja Mahasiswa Universitas Wijaya Putra Tahun 2019 adalah mengoptimalkan fungsi hutan kota Pakal tersebut dengan beberapa program yang melibatkan masyarakat dan karang taruna di RW 01 desa Sidorejo. Salah satu program yang dilaksanakan adalah optimalisasi pemanfaatan hutan kota sebagai tempat berwirausaha dengan membuka lapak lapak makanan dan minuman bagi ibu ibu rumah tangga di RW 01.

\section{METODE}

Kegiatan ini dilakukan di RW 01 Desa Sidorejo Kelurahan Pakal Kecamatan Pakal Kota Surabaya. Pada Bulan Juli - Agustus 2019. Metode yang digunakan adalah pendampingan dan penyuluhan dengan beberapa tahapan pelaksanaan sebagai berikut : pertama, melakukan analisis lingkungan terhadap hutan kota pakal serta analisis terhadap pekerjaan dan kegiatan yang dilakukan oleh ibu ibu rumah tangga yang terdapat di RW 01 desa Sidorejo. Kedua, Menentukan tujuan dan sasaran. Hasil dari pemetaan digunakan untuk menentukan tujuan pendampingan dan penyuluhan tentang optimalisai pemanfaatan hutan kota Pakal.

\section{HASIL DAN PEMBAHASAN}

\section{Keterbatasan dan Keselamatan Akses Masuk Hutan Kota Pakal}

Hutan kota Pakal hanya berjarak lima ratus meter dari jalan raya. Hanya saja untuk menuju ke lokasi hutan kota masih banyak warga masyarakat yang tersesat hal ini dikakarena tidak ada papan penunjuk arah ke hutan kota tersebut. Untuk masuk ke lokasi hutan kota yang dibangun diatas tanah bekas kas desa ini, harus melewati jalan kampung yang hanya memiliki lebar tiga samapi empat meter. Untuk masyarakat yang membawa kendaraan roda empat akan mengalami kesulitan menuju ke lokasi hutan kota. Sehingga sebagai alternatif warga yang akan berkunjung ke lokasi hutan kota ini disarankan mengendarai roda dua atau berjalan kaki. Tetapi kewaspadaan pengunjung hutan kota juga harus dijaga karena sebelum masuk lokasi hutan kota harus melintasi perlintasan kereta api double track yang tidak berpalang pintutu dan juga tidak ada penjaga perlintasan. Padahal perlintasan di pintu masuk hutan kota ini lalu lintas kereta apinya sangat padat seperti KRD, Komuter hingga kereta api cepat jurusan Surabaya-Jakarta.

Undang-Undang Nomor 23 Tahun 2007 tentang Perkeretaapian membawa sebuah misi untuk meniadakan perlintasan sebidang. Jalan raya yang akan melintas rel kereta api harus dibuat di atas (flyover) atau di bawah rel (underpass). Kebijakan ini merupakan hal yang baik dan ideal. Namun dalam hal ini pemerintah tidak boleh menutup mata dengan kondisi yang ada. Terdapat banyak perlintasan yang tidak atau belum memungkinkan dibuat tidak sebidang, baik karena faktor anggaran maupun kondisi geografis. Disisi lain, Undang-Undang tentang Perkeretaapian juga memperbolehkan adanya perlintasan sebidang dengan syarat harus didahului dengan izin resmi dan dilengkapi dengan fasilitas yang dapat menjamin keselamatan pengguna, antara lain rambu/marka, palang pintu, dan petugas jaga lintasan yang kompeten.

Pasal 24 ayat (6) butir b Peraturan Menteri Perhubungan RI Nomor 24 Tahun 2015 tentang Standar Keselamatan Perkeretaapian, perlintasan sebidang harus dilengkapi dengan penjaga pintu perlintasan. Selanjutnya pada ayat (7) huruf f dinyatakan bahwa pada jalur kereta api kecepatan lebih dari $60 \mathrm{~km} / \mathrm{jam}$ dilengkapi dengan pintu perlintasan dan harus dijaga oleh penjaga pintu perlintasan yang telah bersertifikat.

Merujuk pada ketentuan ketentuan diatas maka ketiadaan palang pintu kereta api dan penjaga di Ekonomi, Sosial, dan Budaya

1213 
pintu masuk hutan kota Pakal ini merupakan permasalahan tersendiri bagi keberadaan hutan kota, faktor keselamatan pengunjung adalah hal yang wajib dikaji kembali. Apabila di telusuri lebih lanjut ketentuan tentang keberadaan palang pintu diatur dalam Pasal 77 ayat (2) dan (3) Peraturan Pemerintah Nomor 56 Tahun 2009 tentang Penyelenggaraan Perkeretaapian, dalam peraturan tersebut dijelaskan bahwa untuk menjamin keselamatan dan kelancaran perjalanan kereta api dan lalu lintas jalan, Pada Ayat 2 disebutkan bahwa perpotongan sebidang harus memenuhi persyaratan: a. memenuhi pandangan bebas masinis dan pengguna lalu lintas jalan; $b$. dilengkapi rambu-rambu lalu lintas jalan dan peralatan persinyalan; c. dibatasi hanya pada jalan kelas III (tiga); dan d. memenuhi standar spesifikasi teknis perpotongan sebidang yang ditetapkan oleh Menteri. Selanjutnya Pada Ayat 3 disebutkan bahwa perpotongan sebidang bersifat sementara dan harus dibuat menjadi perpotongan tidak sebidang apabila: (a) salah satu persyaratan pada ayat (2) tidak dipenuhi; (b). frekuensi dan kecepatan kereta api tinggi; dan/atau (c). frekuensi dan kecepatan lalu lintas jalan tinggi.

Dalam Peraturan Menteri Perhubungan RI Nomor 36 Tahun 2011 tentang Perpotongan dan/atau Persinggungan Antara Jalur Kereta Api dengan Bangunan Lain, Pada Pasal 11 dijelaskan bahwa : (1) Perpotongan atau persinggungan dengan jalur kereta api harus mendapat izin dari Direktur Jenderal; (2) Izin sebagaimana dimaksud pada ayat (1) diberikan dengan mempertimbangkan Rencana Induk Perkeretaapian Nasional, Rencana Tata Ruang dan telah memenuhi persyaratan teknis yang diatur dalam Peraturan ini; (3) Perolehan izin sebagaiman dimaksud pada ayat (2) menjadi kewajiban badan hukum atau instansi yang membuat perpotongan dan/atau persinggungan.

Implementasi atas ketentuan Peraturan Menteri No. 36 Tahun 2011 tersebut diatas maka, setiap orang atau pihak yang bermaksud membangun perlintasan sebidang pada jalur kereta api, harus terlebih dahulu mengajukan izin kepada pemilik prasarana perkeretaapian. Terkait dengan perlintasan sebidang yang terletak di lokasi hutan kota Pakal maka Pihak yang berkewajiban mengajukan izin kepada Menteri Perhubungan RI dalam hal ini Direktur Jenderal Perkeretaapian Kementerian
Perhubungan RI terhadap perlintasan sebidang ini adalah Pemerintah Kota Surabaya.

Atas dasar uraian tersebut diatas maka perlu adanya palang pintu perlintasan sebidang yang terdapat di akses masuk Hutan Kota Pakal. Walaupun mekanisme untuk membangun perlintasan dan penjagaan perlintasan kereta api tersebut harus terlebih dahulu mengajukan izin kepada kementrian terkait.

\section{Keterbatasan Lahan Parkir Pengunjung}

Parkir merupakan salah satu komponen suatu sistem transportasi yang perlu dipertimbangkan dalam setiap kebijakan. Selama bepergian dengan menggunakan kendaraan tidak lepas untuk melakukan kegiatan parkir baik kegiatan bekerja, rekreasi dan kegiatan lain. Sedangkan fasilitas parkir adalah lokasi yang ditentukan sebagai tempat pemberhentian kendaraan yang bersifat sementara untuk melakukan kegiatan pada suatu kurun waktu. Fasilitas parkir bertujuan untuk memberikan tempat istirahat kendaraan dan menunjang kelancaran arus lalu lintas (Departemen Perhubungan Darat, 1998).

Standar kebutuhan luas areal parkir berbeda antara satu pusat kegiatan dengan pusat kegiatan lain, tergantung dengan berbagai kebutuhan dan beberapa hal lain antara lain ; pelayanan, ketersediaan ruang parkir, tingkat kepemilikan kendaraan bermotor, dan tingkat pendapatan masyarakat. Kebutuhan ruang parkir yang bersifat tetap berdasarkan Departemen Perhubungan Darat (1998), adalah sebagai berikut : Pusat pedagangan, Pusat perkantoran swasta atau pemerintah, Pusat pedangangan eceran atau pasar swalayan, Pasar, Sekolah, Tempat rekreasi, Hotel dan tempat penginapan dan Rumah sakit.

Hutan Kota Pakal sebagai salah satu tempat rekreasi dan juga merupakan ruang publik maka keberadaan lahan parkir merupakan salah satu komponen yang wajib disediakan oleh pihak pengelola Hutan Kota. Ketentuan ini dapat ditemukan di Pasal 44 Undang-undang Republik Indonesia No.22 Tahun 2009 yang menyebutkan bahwa penetapan lokasi dan pembangunan fasilitas parkir untuk umum dilakukan oleh Pemerintah Daerah dengan memperhatikan: rencana umum tata

$$
\text { Ekonomi, Sosial, dan Budaya }
$$


ruang; analisis dampak lalu lintas; dan kemudahan bagi Pengguna Jasa.

Hutan Kota Pakal yang berfungsi sebagai ruang publik sampai saat ini belum memiliki lahan parkir yang memadai, baik dari aspek kecukupan maupun dari aspek keamanan. Hal inilah yang menjadi salah satu hal yang dikeluhkan oleh warga masyarakat yang berniat untuk mengunjungi hutan kota Pakal. Untuk itu salah satu hal yang dikerjakan oleh Tim KKN di desa Sidorejo ini adalah membuat rambu rambu parkir di lokasi Hutan Kota yang sudah tersedia dengan batas batas yang sudah ditentukan sebelumnya. Tim KKN tidak dapat berbuat banyak dikarenakan Pengelolaan dan Pengadaan sarana Parkir adalah menjadi tanggung jawab pengelola Hutan Kota.

\section{Penataan Lapak Lapak Pedagang Makanan dan Minuman}

Pedagang makanan dan minuman di tempat tempat berlibur memang sangat diperlukan. Hal ini dikarenakan tidak semua pengunjung membawa bekal makanan dan minuman ketika sedang berlibur di suatu tempat. Di hutan kota pakal sendiri telah disediakan lokasi untuk para pedagang untuk tempat berjualan . Saat ini pedagang yang berjualan di lokasi hutan kota mayoritas berasal dari masyarakat desa sidorejo sendiri. Karena pengunjung Hutan kota Pakal sampai saat ini belum terlalu banyak maka masyarakat yang berjualan di lokasi hutan pakal ini pun tidak seberapa banyak. Kenaikan jumlah pengunjung hutan kota ini biasanya terjadi di hari sabtu minggu dan di hari libur nasional. Hal yang perlu mendapatkan perhatian dari pemerintah daerah adalah belum adanya tempat yang representatif bagi pedagang makanan dan minuman di hutan kota pakal ini. Dengan tersedianya tempat sentra makanan dan minuman yang lebih baik diharapkan dapat menambah daya tarik minat pengunjung hutan kota pakal ini.

\section{Program KKN Untuk Optimalisasi Pemanfaatan Hutan Kota}

\section{Lomba Fotografy Hutan Kota Pakal}

Harus diakui bahwa keberadaan hutan kota Pakal sampai saat ini masih belum banyak masyarakat yang mengetahuinya. Hal ini karena pamor hutan pakal masih kalah dengan hutan hutan kota lain yang terdapat di wilayah Surabaya, misalnya hutan kota (hutan bambu) yang terletak di keputih dan hutan kota (mangrove) yang terletak di wonorejo. Salah satu usaha untuk lebih mengenalkan keberadaan hutan kota Pakal ini maka Mahasiswa membuat lomba photo kontes dengan tema eksplorasi hutan kota pakal. Dari kegiatan ini dipilih tiga pemenang dengan hasil photo terbaik yang dinilai oleh tim penilai. Hasil dari foto foto pememang tersebut selanjutnya di upload di berbagai media sosial. Hal yang diharapkan dari kegaiatan ini keberadaan dan keindahan hutan pakal akan lebih dikenal oleh masyarakat luas.

\section{Pembuatan Papan Petunjuk Arah Dan Gerbang Masuk Hutan Kota Pakal}

Minimnya petunjuk arah ke hutan kota pakal menginspirasi mahasiswa KKN untuk membuat beberapa petunjuk arah bagi pengunjung hutan kota pakal. Petunjuk arah ini sangat bermanfaat bagi pengunjung hutan kota yang tidak berasal dari wilayah sekitar. Selain membuat beberapa petunjuk arah mahasiswa juga membuat gerbang selamat datang di pintu masuk hutan kota.

\section{Penyuluhan Kewirausahaan untuk Meningkatkan Pendapatan Keluarga}

Manfaat kewirausahaan adalah dapat membantu menyediakan peluang kesempatan bekerja diberbagai aspek kehidupan manusia, termasuk berbagai kebutuhan konsumen, jasa pelayanan, serta menumbuhkan kesejahteraan dan tingkat kompetisi suatu negara. Selain itu, sejalan dengan perkembangan arus globalisasi, dalam menghadapi tantangan globalisasi kewirausahaan juga semakin menjadi perhatian penting dalam menghadapi kompetisi ekonomi global yang sarat dengan kreativitas dan inovasi (Peterson \& Lee, 2000 dalam Mahanani dan Sari, 2017).

Rahayu dalam Wibowo (2016), menyatakan bahwa wirausahawan merupakan salah satu penopang perekonomian suatu negara, dari wirausahawanlah sebuah negara bisa maju dan berkembang. Untuk menjadi Seorang wirausahawan

$$
\text { Ekonomi, Sosial, dan Budaya }
$$


yang sukses, seorang wirausahaan harus mampu berkomunikasi dengan baik, mengetahui fungsi dan gaya manajemen, menguasai kemampuan manajerial, serta mengetahui dan menguasai cara menjual yang strategis mulai dari pengetahuan tentang produk, ciri khas produk dan daya saing produk terhadap produk yang sejenis. Seseorang yang memiliki bakat kewirausahaan dapat mengembangkan bakatnya melalui pendidikan atau pelatihan kewirausahaan.

Menurut Lestari dan Wijaya (2012), dalam pendidikan kewirausahaan tidak hanya membahas landasan teoritis mengenai konsep kewirausahaan tetapi juga membentuk sikap, perilaku dan pola pikir seorang wirausahawan. Karena pada dasarnya Sikap, perilaku dan pola pikir seseorang akan mempengaruhi niat berwirausaha seseorang

Realisasi Pembahasan Masalah Pelaksanaan kegiatan penyuluhan kewirausahaan pada masyarakat di RW 01 desa Sidorejo Kecamatan Pakal dimaksudkan untuk memberikan penyuluhan kewirausahaan kepada ibu ibu rumah tangga tentang pentingnya pengetahuan kewirausahaan sebelum mereka memulai suatu usaha apapun. Dengan potensi yang dimiliki masyarakat yang ada diharapkan mereka dapat memanfaatkan dan mengimplentasikannya untuk mengatasi berbagai problem hidup serta meningkatkan taraf hidup ke arah yang lebih baik. Dalam kegiatan ini mereka juga diberikan pengetahuan dasar tentang kewirausahaan dan aplikasi kewirausahaan, sehingga semangat kewirausahaan Ibu Ibu rumah tangga dapat dipertahankan bahkan ditumbuhkembangkan. Salah satu manfaat penyuluhan yang diberikan adalah bagaimana cara-cara dan syarat-syarat mendirikan usaha, kriteria apa yang diperlukan sebagai wirausahawan yang sukses, serta pedoman-pedoman berwirausaha. Sehingga mereka secara tidak langsung bisa mandiri dan dapat menambah pendapatan keluarga. Hal ini dapat terwujud jika mendapat dukungan dari semua pihak, mulai dari masyarakat, aparat pemerintah, dan kalangan perguruan tinggi. Penyuluhan kewirausahaan ini sangat erat sekali kaitannya dengan program pemerintah dalam rangka mengentaskan kemiskinan secara umum dan mengurangi angka pengangguran tenaga produktif khususnya dengan memanfaatkan potensi yang dimiliki daerah tersebut. Program penyuluhan wirausaha ini diharapkan akan meningkatkan kesejahteraan keluarga yang merupakan unit terkecil dari masyarakat atau minimal membuka wawasan, pola dan cara berpikir tentang bagaimana memanfaatkan potensi yang ada .

\section{KESIMPULAN}

Hutan Kota pakal yang terletak di wilayah Surabaya Barat adalah satu dari beberapa hutan kota yang terdapat di wilayah kota Surabaya. Dibandingkan dengan hutan kota bambu dan hutan kota mangrove hutan kota pakal masih perlu publikasi yang lebih intensif. Hal ini dikarenakan masih banyak masyarakat yang belum mengetahui keberadaan hutan kota pakal ini. Beberapa keterbatasan yang terdapat di hutan kota pakal ini menjadi bahan bagi mahasiswa KKN Universitas Wijaya Putra Tahun 2019 untuk melakukan pendampingan kepada warga masyarakat di desa Sidorejo yang merupakan salah satu lokasi KKN mahasiswa UWP Surabaya.

Hasil dari pendampingan yang dilaksanakan memberikan dampak positif tidak hanya bagi keberadaan hutan kota pakal tetapi juga warga masyarakat sekitar hutan kota pakal khususnya masyarakat desa Sidorejo.

\section{REFERENSI}

Andayaningsih, (2013) Keanekaragaman Tumbuhan Paku Terestrial di Hutan Kota DKI Jakarta . Berita Biologi. Vo. 12. No. 3.Hal 297-305.

Dahlan E N. 2004. Membangun Kota kebun (Garden City) Bernuansa Hutan kota. IPB Press. Bogor.

Dephub, (1998). Pedoman Perencanaan Dan Pengoperasian Fasilitas Parkir, Jakarta: Departemen Perhubungan, Direktorat Jenderal Perhubungan Darat.

Mahanani, E. \& Sari,B. (2017). Faktor-faktor yang mempengaruhi minat berwirausaha mahasiswa Fakultas Ekonomi Universitas Persada Indonesia Y.A.I. Jurnal Sosial \& Humaniora IKRAITH,2(1),31-40.

$$
\text { Ekonomi, Sosial, dan Budaya }
$$


Peraturan Pemerintah Republik Indonesia Nomor 63 Tahun 2002 tentang Hutan kota.

Peraturan Pemerintah Republik Indonesia Nomor 26 Tahun 2008 Tentang Rencana Tata Ruang Wilayah Nasional.

Peraturan Menteri Perhubungan RI Nomor 36 Tahun 2011 tentang Perpotongan dan/atau Persinggungan Antara Jalur Kereta Api dengan Bangunan Lain.

Undang-Undang Nomor 23 Tahun 2007 Tentang Perkeretaapian

Undang-undang Nomor 22 Tahun 2009 Tentang Lalu Lintas dan Angkutan Jalan

Wibowo, S., \& Pramudana, K., A.,S. (2016). Pengaruh pendidkan kewirausahaan terhadap intensi berwirausaha yang dimediasi oleh sikap berwirausaha. EJurnal Manajemen Unud, 5(12), 8167- 8198
Wijaya, Tony. (2008). Kajian ModelEmpiris Perilaku Berwirausaha UKM DIY dan Jawa Tengah. Jurnal Manajemen dan Kewirausahaan, 10, 93-104. 